\title{
Sistem Pakar Diagnosa Awal Penyakit Kulit Pada Sapi Bali dengan Menggunakan MetodeForward chaining dan Certainty Factor
}

\author{
I Kadek Dwi Gandika Supartha \\ Dosen Sistem Komputer \\ STMIK STIKOM Indonesia \\ Denpasar-Bali, Indonesia \\ dwigandika[at]gmail.com
}

\author{
Ida Nirmala Sari \\ Mahasiswa Teknik Informatika \\ STMIK STIKOM Indonesia \\ Denpasar-Bali, Indonesia
}

\begin{abstract}
BPTU (Balai Pembibitan Ternak Unggul) Sapi Bali merupakan Breeding Centre sapi yang ada di Pulau Bali. Tugas pokok BPTU Sapi Bali adalah melaksanakan pelestarian, pemulian, produksi dan pengembangan serta penyebaran hasil produksi bibit Sapi Bali murni unggul secara nasional. Pencegahan dan pengobatan penyakit pada BPTU Sapi Bali dilakukan oleh dokter hewan. Namun kurangnya dokter hewan yang tidak selalu ada di tempat sehingga dibutuhkan suatu program sistem pakar berbasis desktop yang mampu memberikan diagnosa akan kemungkinan seekor sapi Bali menderita suatu penyakit beserta cara pengobatannya dengan mengunakan metode forward chaining dan Certainty Factor (CF). Proses diagnosa pertama kali dilakukan dengan menggunakan metode forward chaining, jika dengan metode forward chaining tidak menghasilkan penyakit maka akan dilakukan proses dengan metode $\mathrm{CF}$. Menggunakan gabungan dua metode bertujuan untuk menutupi kekurangan dari metode forward chaining.
\end{abstract}

Metode forward chaining melakukan pemrosesan berawal dari sekumpulan gejala yang kemudian dilakukan inferensi hingga menghasilkan diagnose dan metode CF memakai sistem penalaran sebagaimana layaknya seorang pakar, dimana hasil diagnosa disertai nilai CF yang menunjukkan tingkat kebenaran, keakuratan dari kemungkinan penyakit kulit pada sapi Bali di BPTU Sapi Bali.Pengujian sistem menunjukkan bahwa sistem mampu melakukan diagnosa penyakit kulit pada sapi Bali berdasarkan gejala-gejala yang diinputkan pengguna dan dilengkapi dengan definisi serta cara pengobatan. Factor.

Keywords - Sistem Pakar, Forward chaining, Certainty

\section{PENDAHULUAN}

Sistem pakar (Expert System) adalah sistem yang berusaha mengadopsi pengetahuan manusia ke komputer, agar komputer dapat menyelesaikan masalah seperti yang biasa dilakukan oleh para ahli [1]. Tujuan utama pengembangan sistem pakar adalah mendistribusikan pengetahuan dan pengalaman seorang pakar ke dalam sistem komputer. Salah satu bentuk implementasi sistem pakar yang banyak digunakan yakni dalam bidang kedokteran.

BPTU (Balai Pembibitan Ternak Unggul) Sapi Bali merupakan Breeding Centre sapi yang ada di Pulau Bali. Tugas pokok BPTU Sapi Bali adalah melaksanakan pelestarian, pemulian, produksi dan pengembangan serta penyebaran hasil produksi bibit Sapi Bali murni unggul secara nasional. Agar menghasilkan ternak unggul Sapi Bali sangat perlu diperhatikan kesehatan ternak sapi Bali.

Pencegahan dan pengobatan penyakit pada BPTU Sapi Bali dilakukan oleh dokter hewan. Namun kurangnya dokter hewan dan dokter hewan yang bertugas tidak selalu ada di tempat. Para pegawai di BPTU Sapi Bali sangat kesulitan mendiagnosa penyakit pada sapi Bali apabila dokter hewan tidak berada di tempat.

Berdasarkan pemaparan diatas maka dibutuhkan suatu program aplikasi sistem pakar berbasis desktop yang mampu memberikan diagnosa akan kemungkinan seekor sapi Bali menderita suatu penyakit beserta cara pengobatannya dengan mengunakan metode Forward chaining dan Certainty Factor.

\section{SISTEM PAKAR}

Sistem pakar merupakan cabang dari AI (Artificial Inteligent) yang membuat ekstensi khusus untuk spesialisasi pengetahuan guna memecahkan suatu permasalahan pada Human Expert. Human Expert merupakan seseorang yang ahli dalam suatu bidang ilmu pengetahuan tertentu, ini berarti bahwa expert memiliki suatu pengetahuan atau skill khusus yang dimiliki oleh orang lain. Expert dapat memecahkan suatu permasalahan yang tidak dapat dipecahkan oleh orang lain dengan cara efisien.

Pengetahuan di dalam Expert system berasal dari orang atau knowledge yang berasal dari buku-buku referensi, surat kabar atau karya ilmiah orang lain, pengetahuan manusia ke dalam komputer, agar komputer dapat menyelesaikan masalah seperti yang biasa dilakukan oleh para ahli [2]. Atau dengan 
kata lain sistem pakar adalah sistem yang didesain dan diimplementasikan dengan bantuan bahasa pemrograman tertentu untuk dapat menyelesaikan masalah seperti yang dilakukan oleh para pakar dalam hal ini adalah dokter.

Proses inferensi dilakukan dalam suatu modul yang disebut inference engine (mesin inferensi). Ketika representasi pengetahuan pada bagian knowledge base telah lengkap, atau paling tidak telah berada pada level cukup akurat, maka referensi pengetahuan tersebut telah siap digunakan. Sedangkan inferensi engine merupakan modul yang berisi program tentang bagaimana mengendalikan proses reasoning.

Terdapat dua metode umum penalaran yang dapat digunakan apabila pengetahuan dipresentasikan untuk mengikuti aturan-aturan sistem pakar yaitu metode forward chaining dan metode Backward Chaining [1].

\section{METODE FORWARD CHAINING}

Strategi inferensi forward chaining dimulai dengan sekumpulan fakta-fakta pengetahuan, memperoleh fakta-fakta baru menggunakan aturan-aturan dimana premis-premis sesuai dengan fakta-fakta pengetahuan, dan meneruskan prosesnya sampai sebuah tujuan yang ditetapkan telah tercapai.Algoritma forward chaining menurut [1] digambarkan pada gambar 1 berikut ini:

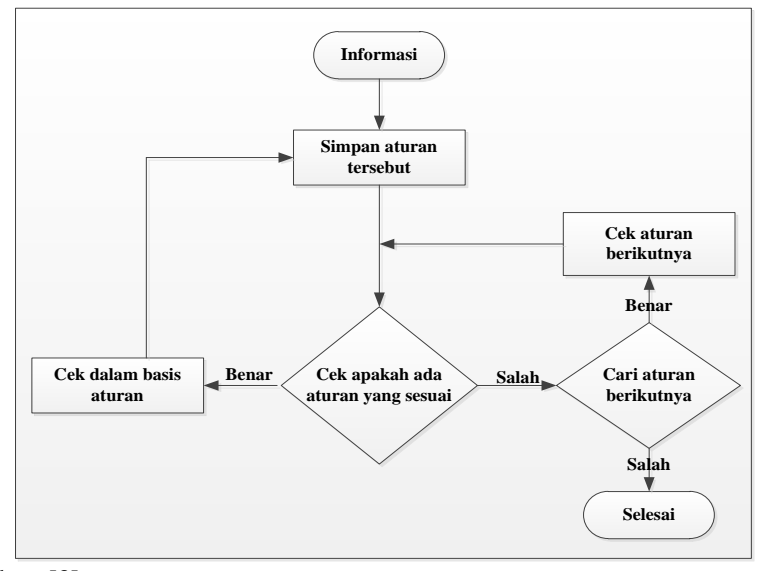

Sumber [3]

Gambar 1. Algoritma Forward chaining

Secara garis besar proses penalaran dengan forward chaining adalah sebagai berikut:

1. Strategi inferensi dimulai dengan diketahui adanya faktafakta.

2. Mendapatkan fakta baru menggunakan aturan-aturan yang premisnya sesuai dengan fakta yang diketahui.

3. Proses tersebut di lanjutkan hingga tujuannya tercapai atau sampai tidak ada lagi aturan yang premisnya sesuai dengan fakta yang ada.

Forward chaining merupakan fakta untuk mendapatkan kesimpulan (conclusion) dari fakta tersebut [1]. Penalaran ini berdasarkan fakta yang ada (data driven), metode ini adalah kebalikan dari metode backward chaining, dimana metode ini dijalankan dengan mengumpulkan fakta-fakta yang ada untuk menarik kesimpulan. Dengan kata lain, prosesnya dimulai dari facts (fakta-fakta yang ada) melalui proses inference fact (penalaran fakta-fakta) menuju suatu goal (suatu tujuan). Metode ini bisa juga disebut menggunakan aturan IF-THEN dimana premise (IF) menuju conclusion (THEN)

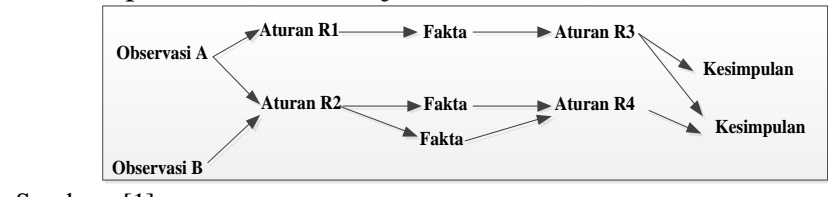

Sumber...[1]

$$
\text { Gambar 2. Proses Forward chaining }
$$

Beberapa kelebihan dan kekurangan dari metode forward chaining yaitu sebagai berikut [3]:

1. Kelebihan metode Forward chaining yaitu:

a. Kelebihan utama dari forward chaining yaitu metode ini akan bekerja dengan baik ketika problem bermula dari mengumpulkan/menyatukan informasi lalu kemudian mencari kesimpulan apa yang dapat diambil dari informasi tersebut.

b. Metode ini mampu menyediakan banyak sekali informasi dari hanya sejumlah kecil data.

c. Merupakan pendekatan paling sempurna untuk beberapa tipe dari problem solving task, yaitu planning, monitoring, control, dan interpretation.

2. Kekurangan metode Forward chaining yaitu:

a. Kelemahan utama metode ini yaitu kemungkinan tidak adanya cara untuk mengenali dimana beberapa fakta lebih penting dari fakta lainnya.

b. Sistem bisa saja menanyakan pertanyaan yang tidak berhubungan. walaupun jawaban dari pertanyaan tersebut penting, namun hal ini akan membingungkan user untuk menjawab pada subjek yang tidak berhubungan

\section{METODE CERTAINTY FACTOR}

Certanity Factor (CF) merupakan nilai parameter klinis yang diberikan MYCIN untuk menunjukkan besarnya kepercayaan. CF menunjukkan ukuran kepastian terhadap suatu fakta atau aturan. CF menunjukkan ukuran kepastian terhadap suatu fakta atau aturan [1]. Notasi faktor kepastian adalah:

$$
C F[h, e]=M B[h, e]-M D[h, e]
$$

Dengan:

$\mathrm{CF}[\mathrm{h}, \mathrm{e}] \quad=$ faktor kepastian

$\mathrm{MB}[\mathrm{h}, \mathrm{e}]=$ ukuran kepercayaan terhadap hipotesis $\mathrm{h}$, jika diberikan evidence e (antara 0 dan 1)

$\mathrm{MD}[\mathrm{h}, \mathrm{e}]=$ ukuran ketidakpercayaan terhadap hipotesa $\mathrm{h}$, jika diberikan evidence e (antara 0 dan 1$)$

$\mathrm{e} \quad=$ evidence (peristiwa atau fakta)

$\mathrm{h} \quad=$ hipotesa (dugaan) 
Kelebihan Certainty Factor:

1. Metode ini cocok dipakai dalam sistem pakar untuk mengukur sesuatu apakah pasti atau tidak pasti dalam mendiagnosa penyakit.

2. Perhitungan dengan menggunakan metode ini dalam sekali hitung hanya dapat mengelola dua data saja sehingga keakuratan data dapat terjaga.

Kekurangan Metode Certainty Factor:

1. Ide umum dari pemodelan ketidakpastian manusia dengan menggunakan numerik metode Certainty Factors biasanya diperdebatkan. Sebagian orang akan membantah pendapat bahwa formula untuk metode Certainty Factor diatas memiliki sedikit kebenaran.

2. Metode ini hanya dapat mengolah ketidakpastian/kepastian hanya dua data saja. Perlu dilakukan beberapa kali pengolahan data untuk data yang lebih dari dua buah.

3. Nilai CF yang diberikan bersifat subyektif karena penilaian setiap pakar bisa saja berbeda-beda tergantung pengetahuan dan pengalaman pakar.

\section{PenYakit Kulit PAdA SAPI Bali}

Berbagai jenis penyakit kulit sapi Bali yang disebabkan oleh virus secara primer tidak menyebabkan sakit atau hanya memperlihatkan gejala ringan. Sebaliknya, dapat menyebabkan penyakit akut atau mematikan [4]. Berikut ini adalah jenis-jenis penyakit pada sapi Bali seperti:

1. Pityriasis (ketombe)

2. Parakeratotosis

3. Hiperkeratosis

4. Skabies

5. Impetigo

6. Oedema Angioneurotik (Angioneurotik edema)

7. Urtikaria (Biduren)

8. Limfangitis (Radang Saluran Limfa)

9. Sela Karang (Saccharomycosis)

10. Kadas

11. Dermatitis (Radang Kulit)

12. Luka bakar

13. Kudis

14. Ekstoparasit (Penyakit kulit oleh caplak, kutu, lalat dan nyamuk)

\section{DATA FLOW DIAGRAM (DFD)}

Pada tahun 1967, Martin dan Estrin memperkenalkan suatu algoritma program dengan menggunakan symbol lingkaran dan panah untuk mewakili arus data. E. Yourdan dan L.L. Constantine juga menggunakan notasi symbol ini untuk menggambarkan arus data dalam perancangan program. G.E.Whitehouse tahun 1973 juga menggunakan notasi semacam ini untuk membuat model-model system matematika. Penggunaan notasi dalam diagram arus data ini sangat membantu sekali untuk memahami suatu sistem pada semua tingkat kompleksitasnya seperti yang diungkapkan oleh Chris Gane dan Trish Sarson. Pada tahap analisis, penggunaan notasi ini sangat membantu sekali di dalam komunikasi dengan pemakai sistem untuk memahami sistem secara logika. Diagram yang menggunakan notasi-notasi ini untuk menggambarkan arus dari system sekarang dikenal dengan nama diagram arus data (data flow diagram atau DFD) [5]

DFD sering digunakan untuk menggambarkan suatu sistem yang telah ada atau sistem baru yang akan dikembangkan secara logika tanpa mempertimbangkan lingkungan fisik dimana data tersebut mengalir (misalnya lewat telpon, surat dan sebagainya) atau lingkungan fisik dimana data tersebut disimpan (misalnya file kartu, microfiche, harddisk, tape, diskette dan lain sebagainya). DFD merupakan alat yang cukup popular sekarang ini, karena dapat menggambarkan arus data di dalam sistem dengan terstruktur dan jelas. Lebih lanjut DFD juga merupakan dokumentasi dari sistem yang baik [4].

\section{GAMBARAN UMUM SISTEM}

Gambaran umum sistem dari sistem pakar diagnosa awal penyakit kulit pada sapi bali dapat dilihat dari Gambar 3 dibawah ini.

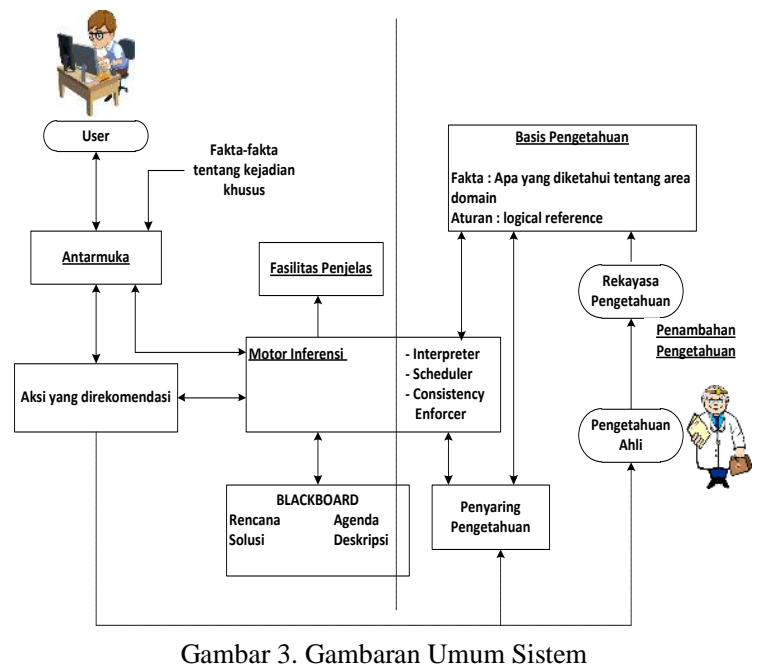

Komponen-komponen yang terdapat pada gambaran umum sistem diagnosa awal penyakit kulit pada sapi yaitu:

1. Subsistem penambahan pengetahuan.

Pada bagian ini digunakan untuk memasukkan pengetahuan, mengkrontruksi atau memperluas pengetahuan tentang penyakit, gejala, dan cara pengobatan penyakit kulit pada sapi Bali dalam basis pengetahuan. Pengetahuan yang diperoleh berasal dari ahli yaitu dokter hewan dan dari buku. 
2. Basis Pengetahuan

Basis pengetahuan adalah pengumpulan data-data dari seorang pakar kedalam sistem (program komputer). Sumber-sumber pengetahuan yang didapat pada penelitian ini didapat dari pakar dan buku. Adapun sumber-sumber yang ada dapat dilihat sebagai berikut:

1. Buku

Adapun buku-buku yang digunakan adalah sebagai berikut:

- Subronto, 2003. Ilmu Penyakit Ternak (mamalia), Gadjah Mada University Press, Yogyakarta.

- Tim Pusat Kajian Sapi Bali - Unud, 2012. Sapi Bali Sumberdaya Genetik Asli Indonesia, Udayana University Press, Denpasar.

2. Pakar

Adapun pakar yang ditemui untuk melakukan konsultasi tentang penyakit kulit pada sapi adalah sebagai berikut:

- Drh. Edi Suprapto

- Drh. Slamet Hartono

Untuk memperoleh data dari pakar digunakan sebuah form yang sudah berisikan gejala dan diagnosa penyakit yang diperoleh dari buku. Pakar hanya memberikan nilai $\mathrm{MD}$ dan $\mathrm{MB}$ sesuai dengan teori $\mathrm{CF}$, karena menggunakan 2 orang pakar maka nilai $\mathrm{CF}$ dari masingmasing pakar akan dijumlahkan dan dibagi dua. Contoh form dapat dilihat pada Gambar 4 dibawah ini :

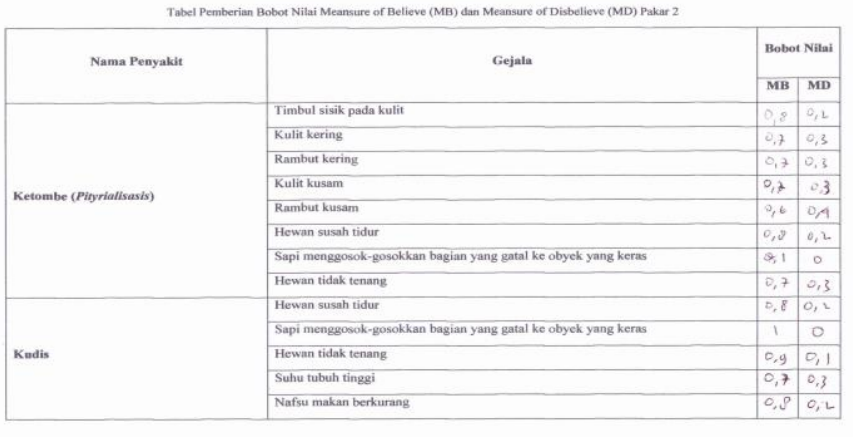

Gambar 4. Form Pemberian Bobot Nilai

Sumber pengetahuan tersebut dijadikan sebagai informasi untuk dipelajari, diolah dan diorgansikan secara terstruktur menjadi basis pengetahuan. Sumber pengetahuan tersebut harus diperoleh dengan kemampuan untuk mengolah data-data yang tersedia menjadi solusi yang efisien.

3. Mesin Inferensi

Pada mesin inferensi ini, data yang telah diinput Pegawai BPTU Sapi Bali akan di proses pada mesin inferensi dengan menggunakan metode forward chaining dan Certainty Factor, berdasarkan gejala yang dimasukan, kemudian gejala-gejala tersebut akan dikelompokkan sesuai dengan jenis penyakit yang diderita, dan akan dilakukan pemeriksaan pada basis pengetahuan apakah gejala tersebut merupakan salah satu jenis penyakit kulit pada sapi Bali. Kemudian akan diberikan rekomendasi berupa cara pengobatan.

\section{Blackboard}

Blackboard digunakan untuk menggambarkan masalah dan mencatat hasil diagnosa sementara sebelum mendapatkan solusi terakhir penyakit kulit pada sapi Bali. Tipe-tipe keputusan yang disimpan pada Blackboard adalah rencana yaitu bagaimana memecahkan persoalan terkait dengan penyakit kulit pada sapi Bali. Agenda yaitu aksi potensial yang menunggu eksekusi. Hipotesa dan aksi yang akan diproses dalam solusi.

5. Interface atau antarmuka

Pada bagian antarmuka Pegawai BPTU Sapi Bali melakukan dialog secara langsung dengan sistem, dimana sistem akan memberikan pertanyaan-pertanyaan menyangkut gejala penyakit kulit pada sapi Bali, dan mengelompokkan gejala tersebut ke dalam jenis penyakit kulit yang di derita oleh sapi Bali, kemudian sistem akan memberikan solusi yang telah diproses pada mesin inferensi dengan menggunakan 2 metode yaitu forward chaining dan Certainty Factor.

6. Fasilitas Penjelas

Fasilitas penjelasan merupakan proses diagnosa sistem dengan mengambil data dari pengetahuan, dengan cara menjawab pertanyaan-pertanyaan yang di input oleh user atau Pegawai BPTU Sapi Bali berdasarkan input yang diberikan oleh user, kemudian memberikan solusi terhadap permasalahan berupa diagnosa penyakit yang diderita sapi sesuai dengan fakta diberikan dokter dan memberikan rekomendasi cara pengobatannya.

7. Fasilitas Perbaikan Pengetahuan

Adanya evaluasi perbaikan sistem pakar akan menghasilkan basis pengetahuan yang lebih baik serta penalaran yang lebih efektif dalam melakukan diagnosa penyakit kulit pada sapi Bali.

\section{METODE INFERENSI SISTEM PAKAR}

Perancangan sistem pakar diagnosa awal penyakit kulit pada sapi Bali ini menggunakan dua metode yaitu metode Forward Chaining dan metode Certainty Factor. Dimana dalam proses pelacakannya metode Forward Chaining yang lebih diutamakan. Mekanisme mesin inferensi dengan menggunakan metode Forward Chaining dan metode Certainty Factor adalah seperti Gambar 5 dibawah ini. 


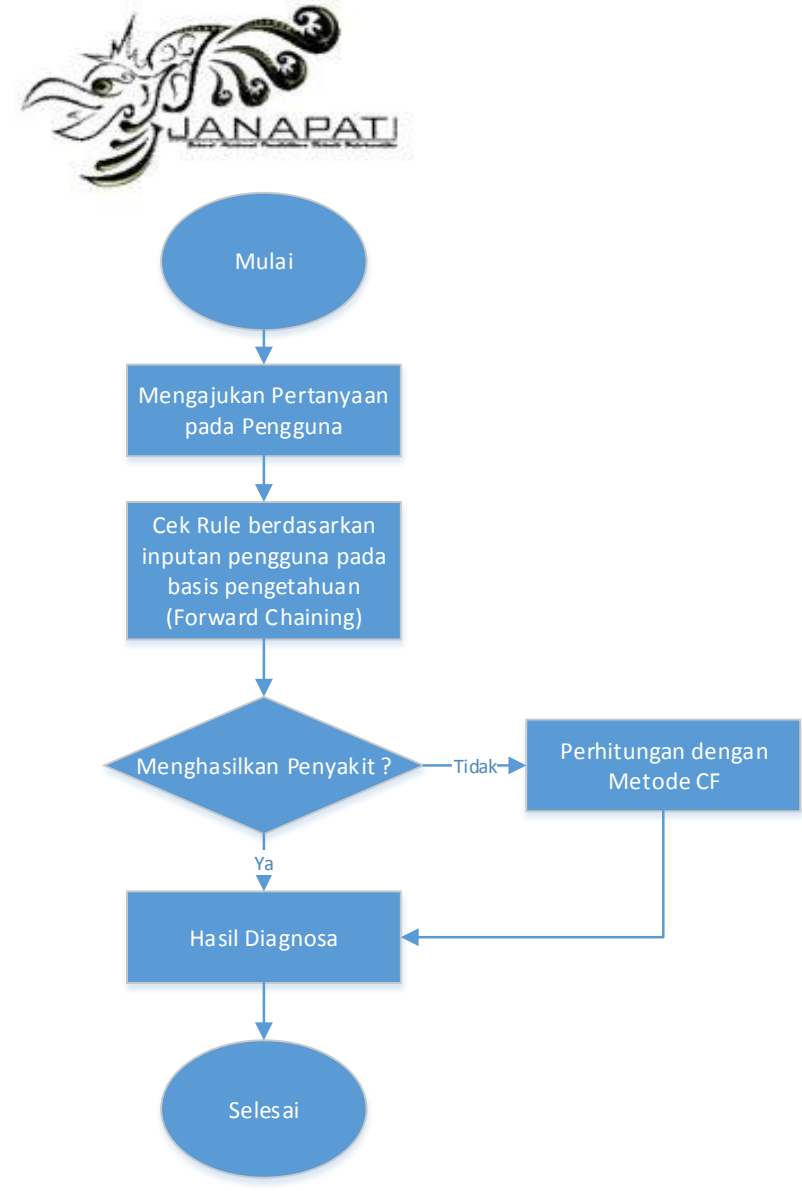

Gambar 5 Metode Inferensi

\section{IMPLEMENTASI SISTEM}

Implementasi sistem dilakukan setelah proses perancangan dan pembuatan aplikasi selesai, kegiatan dalam implementasi ini yaitu mengecek apakah semua fungsi dari aplikasi sesuai dengan perancangan yang telah dilakukan sebelumnya.

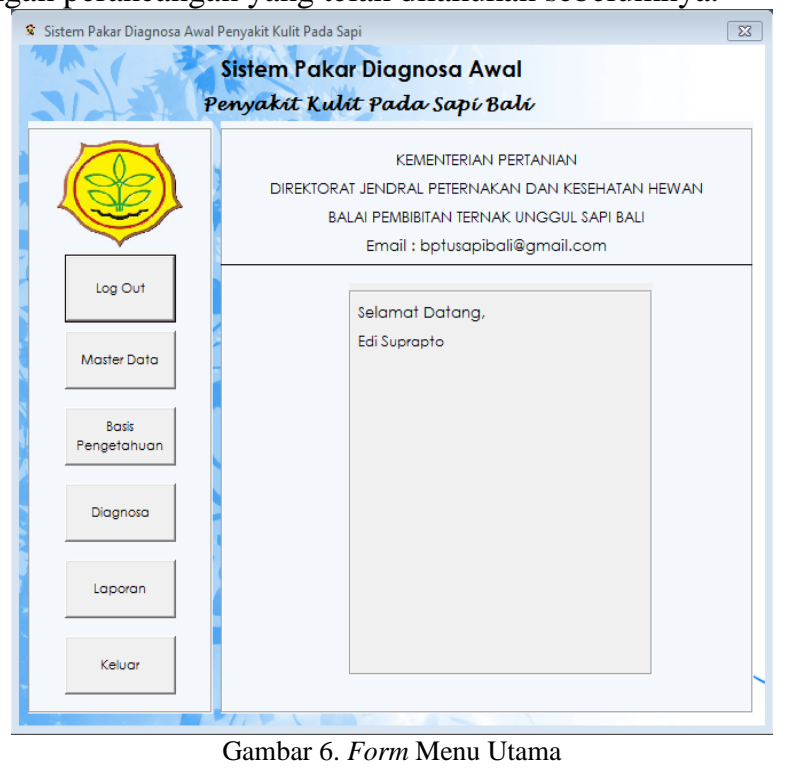

Pada Gambar 6. Ditampilkan Form Menu Utama dimana pada form tersebut terdapat 5 button yaitu Login, Master Data
ISSN 2089-8673

Jurnal Nasional Pendidikan Teknik Informatika (JANAPATI)

Volume 3, Nomor 3, Desember 2014

yang terdiri dari data user, data gejala, dan data penyakit, Basis Pengetahuan, Diagnosa, Laporan yang terdiri dari laporan penyakit, dan tombol Keluar. Untuk melakukan proses diagnosa penyakit kulit pada sapi Bali klik tombol Diagnosa kemudian akan muncul Form Daftar Sapi seperti Gambar 7 berikut.

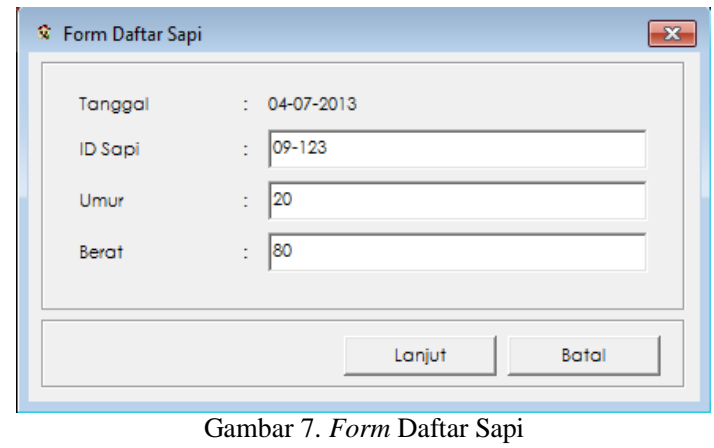

Untuk melanjutkan proses diagnosa klik tombol lanjut dan akan muncul Form Konfirmasi Diagnosa seperti Gambar 8 berikut.

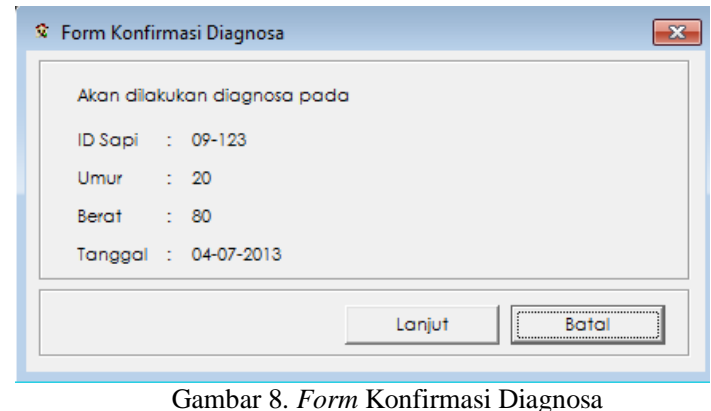

Untuk melanjutkan proses diagnosa pilih lanjut, maka akan ditampilkan Form Diagnosa penyakit kulit pada sapi Bali seperti Gambar 9 berikut.

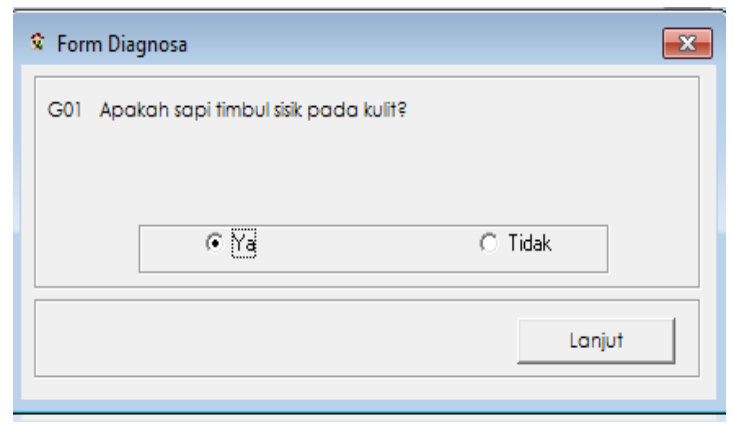

Gambar 9. Form Diagnosa

Pada proses diagnosa sistem akan memberikan pertanyaan-pertanyaan yang berkaitan dengan gejala penyakit kulit pada sapi Bali. Terdapat 2 pilihan jawaban yang bisa $u s e r$ pilih yaitu ya dan tidak. Tombol lanjut digunakan untuk melanjutan proses diagnosa ke pertanyaan selanjutnya setelah user memilih jawaban ya atau tidak sampai sistem muncul form hasil diagnosa. Form hasil diagnosa ada dua yaitu form hasil diagnosa dengan hasil diagnosa menggunakan metode forward chaining dan metode Certainty Factor. Tampilan 
ISSN 2089-8673

Jurnal Nasional Pendidikan Teknik Informatika (JANAPATI)

Volume 3, Nomor 3, Desember 2014

form diagnosa dengan hasil diagnosa menggunakan metode forward chaining.

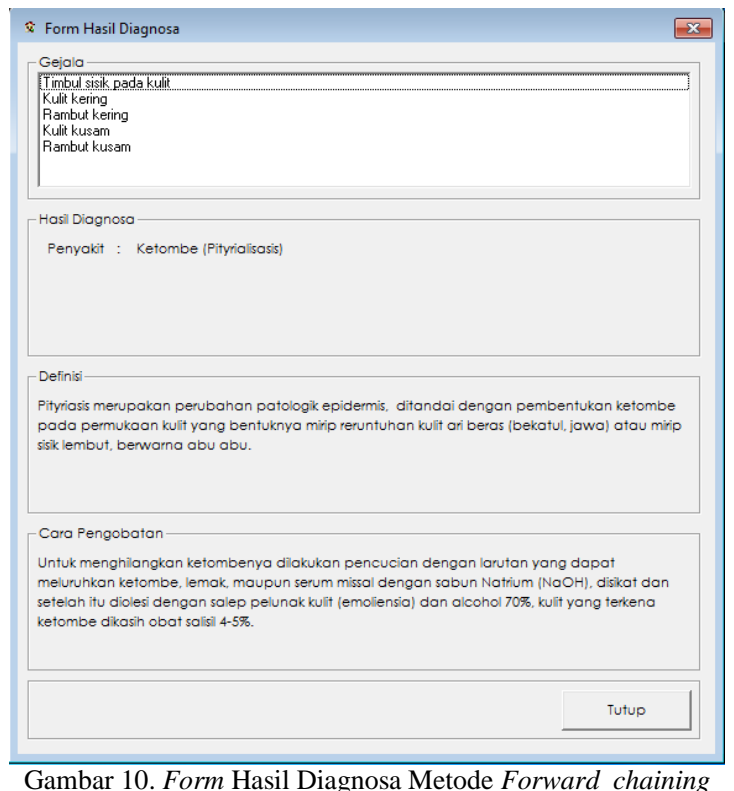

Form hasil diagnosa dengan metode forward chaining berisikan hasil diagnosa penyakit yang diderita sapi. Pada form hasil diagnosa akan ditampilkan gejala, penyakit, definisi penyakit dan cara pengobatan penyakit yang diderita oleh sapi yang dilakukan diagnosa.

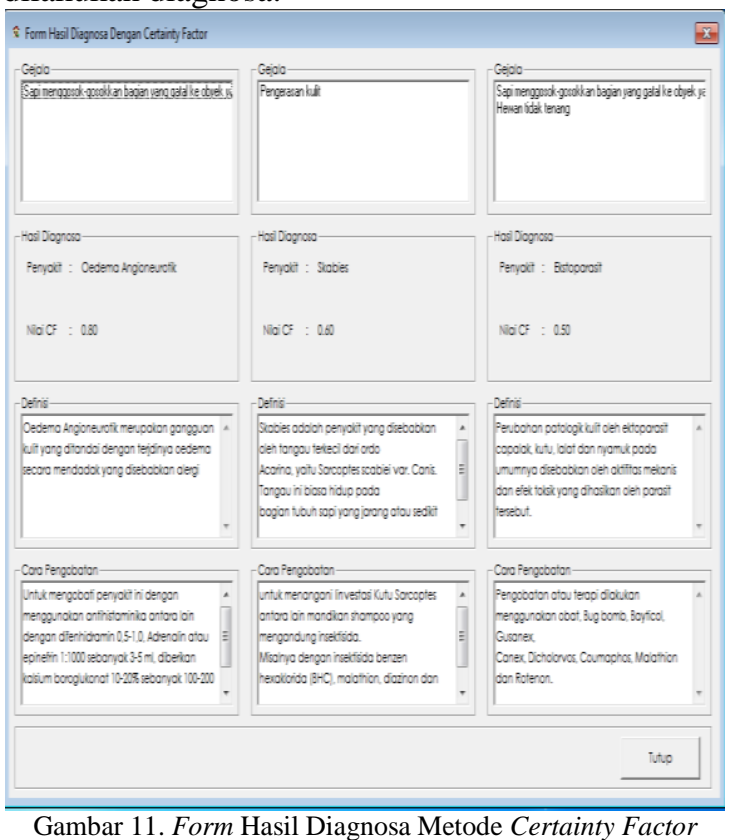

Pada form hasil diagnosa menggunakan metode Certainty Factor akan dimunculkan 3 penyakit yang memiliki nilai $\mathrm{CF}$ tertinggi. Pada form hasil diagnosa menggunakan metode
Certainty Factor akan dimunculkan gejala, penyakit beserta nilai Certainty Factor dari masing-masing penyakit yang muncul, definisi dari penyakit dan cara pengobatan masingmasing penyakit yang muncul.

\section{Pengujian Sistem}

Pengujian sistem pakar ini akan menggunakan pengujian black box yang akan memeriksa jalannya sistem apakah telah sesuai atau tidak. Pemilihan data pengujian dilakukan dengan menggunakan data yang tidak diperbolehkan (illegal values), data yang kosong (null) dan data yang benar. Berikut ini pengujian yang telah dilakukan dan hasilnya telah sesuai dengan apa yang diharapkan. Pengujian yang telah dilakukan antara lain yaitu:

Tabel 1 Pengujian Input Data User

\begin{tabular}{|c|c|c|c|c|}
\hline Input & \multicolumn{2}{|c|}{ Contoh Data } & $\begin{array}{c}\text { Hasil } \\
\text { Eksekusi }\end{array}$ & $\begin{array}{c}\text { Keteranga } \\
\mathbf{n}\end{array}$ \\
\hline \multirow{6}{*}{$\begin{array}{c}\text { Data } \\
\text { yang } \\
\text { tidak } \\
\text { diperbole } \\
\text { hkan } \\
\text { (illegal } \\
\text { values) }\end{array}$} & Nama User & $\begin{array}{c}\text { Edi } \\
\text { Suprapto }\end{array}$ & \multirow{6}{*}{$\begin{array}{c}\text { Tidak } \\
\text { Berhasil }\end{array}$} & \multirow{6}{*}{$\begin{array}{l}\text { Muncul } \\
\text { Pesan: } \\
\text { Password } \\
\text { Melebihi } \\
10 \text { karakter }\end{array}$} \\
\hline & Alamat & $\begin{array}{c}\text { Banyuwang } \\
\text { i }\end{array}$ & & \\
\hline & Jenis Kelamin & $\mathrm{L}$ & & \\
\hline & Username & edisuprapto & & \\
\hline & Password & $\begin{array}{c}\text { edi1234567 } \\
8 \\
\end{array}$ & & \\
\hline & Jenis User & Pakar & & \\
\hline & Nama User & $\begin{array}{c}\text { Edi } \\
\text { Suprapto }\end{array}$ & & \\
\hline Data & Alamat & $\begin{array}{c}\text { Banyuwang } \\
\text { i }\end{array}$ & & $\begin{array}{l}\text { Muncul } \\
\text { Pesan: }\end{array}$ \\
\hline & Jenis Kelamin & & Tidak & \\
\hline $\begin{array}{l}\text { kosong } \\
\text { (null) }\end{array}$ & Username & & & Tidak \\
\hline & Password & & & $\begin{array}{l}\text { Boleh } \\
\text { Kosong }\end{array}$ \\
\hline & Jenis User & & & \\
\hline & Nama User & $\begin{array}{c}\text { Edi } \\
\text { Suprapto }\end{array}$ & & \\
\hline & Alamat & $\begin{array}{c}\text { Banyuwang } \\
\text { i }\end{array}$ & & \\
\hline $\begin{array}{l}\text { Data } \\
\text { yang }\end{array}$ & Jenis Kelamin & $\mathrm{L}$ & Berhasil & \\
\hline benar & Username & edisuprapto & & \\
\hline & Password & 123456 & & \\
\hline & Jenis User & Pakar & & \\
\hline
\end{tabular}

Tabel 2Pengujian Input Data Gejala

\begin{tabular}{|c|c|c|c|c|}
\hline \multirow{2}{*}{ Input } & \multicolumn{2}{|c|}{ Contoh Data } & $\begin{array}{c}\text { Hasil } \\
\text { Eksekusi }\end{array}$ & $\begin{array}{c}\text { Keteranga } \\
\text { n }\end{array}$ \\
\hline \multirow{3}{*}{$\begin{array}{c}\text { Data yang } \\
\text { kosong (null) }\end{array}$} & ID Gejala & G01 & & $\begin{array}{c}\text { Muncul } \\
\text { Pesan: } \\
\end{array}$ \\
\cline { 2 - 3 } & Nama Gejala & & Tidak & Gejala \\
& & Berhasil & Tidak \\
& & & Boleh \\
& & & Kosong \\
\hline
\end{tabular}




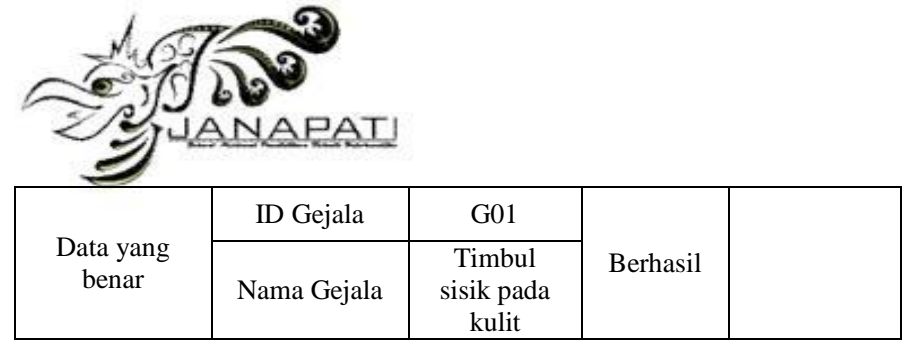

Tabel 3 Pengujian Input Data Penyakit

\begin{tabular}{|c|c|c|c|c|}
\hline Input & \multicolumn{2}{|c|}{ Contoh Data } & $\begin{array}{c}\text { Hasil } \\
\text { Eksekusi }\end{array}$ & Keterangan \\
\hline \multirow{7}{*}{$\begin{array}{c}\text { Data } \\
\text { yang } \\
\text { kosong } \\
(\text { null })\end{array}$} & ID Penyakit & P01 & \multirow{7}{*}{$\begin{array}{c}\text { Tidak } \\
\text { Berhasil }\end{array}$} & \multirow{7}{*}{$\begin{array}{c}\text { Error: } \\
\text { Harus } \\
\text { menginputkan } \\
\text { data gejala } \\
\text { beserta nilai } \\
\text { MB dan MD }\end{array}$} \\
\hline & $\begin{array}{c}\text { Nama } \\
\text { Penyakit }\end{array}$ & $\begin{array}{c}\text { Ketombe } \\
\text { (Pityrialisas } \\
\text { is) }\end{array}$ & & \\
\hline & Definisi & $\begin{array}{c}\text { Ketombe } \\
\text { adalah }\end{array}$ & & \\
\hline & $\begin{array}{c}\text { Cara } \\
\text { Pengobatan }\end{array}$ & $\begin{array}{c}\text { Memberika } \\
\text { n Obat }\end{array}$ & & \\
\hline & Gejala & & & \\
\hline & MB & & & \\
\hline & MD & & & \\
\hline \multirow{7}{*}{$\begin{array}{l}\text { Data } \\
\text { yang } \\
\text { benar }\end{array}$} & ID Penyakit & P01 & \multirow{7}{*}{ Berhasil } & \\
\hline & $\begin{array}{c}\text { Nama } \\
\text { Penyakit }\end{array}$ & $\begin{array}{l}\text { Ketombe } \\
\text { (Pityrialisas } \\
\text { is) }\end{array}$ & & \\
\hline & Definisi & $\begin{array}{c}\text { Ketombe } \\
\text { adalah }\end{array}$ & & \\
\hline & $\begin{array}{c}\text { Cara } \\
\text { Pengobatan }\end{array}$ & $\begin{array}{c}\text { Memberika } \\
\text { n Obat }\end{array}$ & & \\
\hline & Gejala & G01 & & \\
\hline & MB & 0.85 & & \\
\hline & MD & 0.15 & & \\
\hline
\end{tabular}

\section{Pengujian Diagnosa}

Pengujian kebenaran sistem dilakukan untuk mengetahui kesamaan hasil akhir atau output yang berupa kemungkinan jenis penyakit yang dihasilkan oleh sistem dengan yang dihasilkan oleh perhitungan manual berdasarkan metode yang digunakan yaitu metode forward chaining dan Certainty Factor.

Pengujian dengan metode forward chaining akan dicocokan dengan aturan basis pengetahuan yang telah ditentukan. Pengujian kebenaran sistem dengan metode Certainty Factor dilakukan dengan melakukan beberapa uji coba diantaranya adalah sebagai berikut:

a. Dengan satu gejala satu jenis penyakit

b. Dengan satu gejala beberapa jenis penyakit

c. Dengan beberapa gejala satu jenis penyakit

d. Dengan beberapa gejala beberapa jenis penyakit

\section{ANALISIS Hasil PERANCANGAN DAN PENGUJIAN SISTEM}

Berikut ini adalah analisis hasil perancangan dan pengujian sistem pakar diagnosa awal penyakit kulit pada sapi Bali
ISSN 2089-8673

Jurnal Nasional Pendidikan Teknik Informatika (JANAPATI)

Volume 3, Nomor 3, Desember 2014

dengan menggunakan metode Forward chaining dan Certainty Factor:

1. Sistem menampilkan hasil diagnosa beserta gejala yang dipilih ya, nama penyakit, definisi dan cara pengobatannya.

2. Sistem menampilkan nilai kepercayaan (CF) pada setiap hasil diagnosa dengan menggunakan metode Certainty Factor yang berguna untuk memperkuat keyakinan user akan penyakit yang di derita oleh sapi Bali pada BPTU Sapi Bali.

3. Pengujian sistem dilakukan dengan menggunakan metode Black Box dimana data yang mudah diperiksa akan dapat mudah dieksekusi oleh sistem sesuai dengan keinginan.

4. Saat user melakukan inputan data kosong ( $n u l l)$ dan data yang tidak diperbolehkan (illegal values) sistem akan menampilkan pesan kesalahan dan tidak mengeksekusi proses yang dilakukan oleh user.

5. Saat user menginputkan data dengan lengkap dan benar, maka sistem akan menegksekusi proses tersebut dan melakukan penyimpanan sesuai dengan yang diinginkan.

6. Sistem tidak membenarkan pengguna memasukkan datadata yang sama. Ini dikarenakan data-data seperti user, gejala dan penyakit memiliki atribut yang unik.

7. Sistem pakar ini dapat membantu user berupa pakar dan pegawai di BPTU Sapi Bali untuk melakukan diagnosa awal pada sapi Bali di mana dapat melakukan penanganan dini terhadap penyakit yang di derita oleh sapi Bali.

8. Sistem ini memungkinkan pengguna untuk mengembangkan representasi pengetahuan (gejala dan penyakit) yang ada.

\section{PENUTUP}

Setelah dilakukan analisis dan pengujian terhadap Sistem Pakar Diagnosa Awal Penyakit Kulit pada Sapi Bali dengan Menggunakan Metode forward chaining dan Certainty Factor, dapat disimpulkan bahwa:

1. Sistem ini dapat digunakan untuk mengetahui jenis penyakit yang di dialami oleh sapi Bali di BPTU Sapi Bali berdasarkan inputan gejala-gejala yang dimasukan oleh user.

2. Sistem ini mampu menyimpan representasi pengetahuan pakar dengan metode Foward Chaining dan Certainty Factor berdasarkan nilai Measure of Believe (MB) dan Measure of Disbelieve (MD).

3. Selain menghasilkan penyakit sistem pakar ini dapat menjelaskan definisi dan cara pengobatan penyakit kulit pada sapi Bali.

4. Dengan menggunakan sistem ini dapat dijadikan solusi alternatif bagi dokter hewan dan pegawai di BPTU Sapi Bali untuk melakukan diagnosa awal terhadap gejalagejala suatu penyakit yang diderita oleh sapi Bali. 
ISSN 2089-8673

Jurnal Nasional Pendidikan Teknik Informatika (JANAPATI)

Volume 3, Nomor 3, Desember 2014

5. Dari hasil pengujian perhitungan $\mathrm{CF}$ manual dan output $\mathrm{CF}$ dari sistem menghasilkan penyakit dan nilai Certainty Factor yang sama. Hal ini menunjukkan bahwa hasil perancangan dan implementasi sistem sudah sesuai.

6. Dengan menggunakan dua metode forward chaining dan Certainty Factor pada proses diagnosa dapat menutupi kekurangan dari metode forward chaining.

\section{REFERENSI}

[1] Kusumadewi S, 2003. Artificial Intelegence (Teknik dan Aplikasinya), Graha Ilmu, Yogyakarta.

[2] Arhami, Muhammad, 2005. Konsep Dasar Sistem Pakar. Andi, Yogyakarta.

[3] Durkin, J., 1994. Expert Systems Design and Development, Prentice Hall International Inc., New Jersey.

[4] Subronto, 2003. Ilmu Penyakit Ternak (Mamalia), Gadjah Mada University Press, Yogyakarta.

[5] Jogiyanto HM, MBA, Akt, 2005. Analisa dan Desain, Andi, Yogyakarta.

[6] Tim Pusat Kajian Sapi Bali - Unud, 2012. Sapi Bali Sumberdaya Genetik Asli Indonesia, Udayana University Press, Denpasar 